\title{
El catálogo general y el inventario de bienes reconocidos como instrumentos de protección del patrimonio histórico andaluz. Cuestiones procedimientales y competencias municipales
}

\author{
Isabel González Ríos \\ Profesora Titular de Derecho Administrativo. Universidad de Málaga \\ isa_gonzales@uma.es
}

Recibido: 20 de agosto de 2012 Aceptado: 24 de mayo de 2013

\begin{abstract}
Resumen
Este trabajo de investigación analiza las competencias que corresponden a la Administración estatal, autonómica y local en materia de protección y fomento del patrimonio histórico y cultural, prestando especial atención a las competencias municipales; para posteriormente centrarnos en el estudio de los instrumentos de protección del patrimonio histórico andaluz, el Catálogo General y el Inventario de Bienes Reconocidos, en los que aquellas competencias se proyectan. Así, nuestro objeto de estudio son los bienes que los integran, el procedimiento de inscripción y el régimen jurídico aplicable a los titulares o poseedores de los bienes inscritos. $Y$ todo ello, analizando no solo la Ley de Patrimonio Histórico Andaluz de 2007, sino también, la normativa estatal relacionada y la jurisprudencia referente al tema.
\end{abstract}

\section{The General Catalogue and the Inventory of goods recognised like instruments of protection of the historical heritage Andalusian. Questions of procedure and competitions of the municipalities}

\footnotetext{
Abstract

This work of investigation analyses the competitions that correspond to the state Administration, regional and local in matter of protection and promotion of the historical and cultural heritage, loaning special attention to the municipal competitions; for later centre us in the study of the instruments of protection of the historical heritage Andalusian, the General Catalogue and the Inventory of Goods Recognised, in which those competitions are projected. Like this, our object of study are the goods that integrate them, the procedure of registration and the applicable juridical diet to the headlines or possessors of the goods inscribed. And all this, analysing not only the Law of Historical Heritage Andalusian of 2007 , but also, the state rule related and the jurisprudence concerning the subject.
} 


\section{LA PROTECCIÓN DEL PATRIMONIO HISTÓRICO COMO FUNCIÓN PÚBLICA. LA DESTACADA LABOR MUNICIPAL}

La protección del patrimonio histórico es una función pública' que en sentido amplio entendemos que hace alusión a todo el régimen jurídico aplicable a dichos bienes (la Administración competente, los instrumentos de protección de los bienes que lo integran y el régimen jurídico que les resulta aplicable, las medidas de conservación y fomento, las medidas de control de la exportación y expoliación y el régimen de inspección y sanción). Sin embargo, en la legislación reguladora de dicho patrimonio -a la que nos referimos a continuación- el régimen de protección de los bienes históricos se identifica con los instrumentos para su tutela y con el régimen jurídico general que deriva de su inclusión en dichos instrumentos de protección. Concepto más estricto, que nosotros seguimos en este trabajo.

\section{A. Competencias estatales y autonómicas. Marco normativo regulador}

El patrimonio histórico es una materia de competencia compartida entre el Estado y las CCAA como se deduce de la CE (art. 149.1.28, 149.2 y art. 148.15, 16 y 17) y ha puesto de manifiesto el Tribunal Constitucional' ${ }^{2}$. Así, todas las CCAA han asumido competencias y regulado esta materia, utilizando predominantemente en sus normas reguladoras la denominación más amplia de patrimonio cultural ${ }^{3}$. En Andalucía las disposiciones aprobadas sobre patrimonio histórico tienen su fundamento en el art. 68 del Estatuto de Autonomía de Andalucía 4 por el que se asumen competencias sobre "Cultura y patrimonio". Lo que no impide que la cultura sea una materia am-

1 Esa función pública se configura como un principio rector que debe regir las políticas publicas que desarrollen los poderes públicos. Así se deduce del art. 46 de la CE, y en similares términos del art. 37, apdos. $17^{\circ}$ y $18^{\circ}$ del Estatuto de Autonomía de Andalucía.

2 Entre otras, en su STC 17/91, de 31 de enero (Pte. J. Gabaldón López) y en la STC de 5 de abril de 1984 (Pte. J.Arozamena Sierra).

Sobre la distribución de competencias en materia de patrimonio histórico, vid, entre otros: Alegre Ávila, J.M. (1994): 641 y ss; Abad Liceras, J.M. (1999); Pérez de Armiñan, A. (1997): 57 y ss.

3 Así, el País Vasco, Cataluña, Galicia, Asturias, Cantabria, Murcia, Comunidad Valenciana, Aragón, Navarra y Castilla y León. Solo Andalucía, Castilla-La Mancha, Canarias, la Comunidad Autónoma Balear y Madrid optan por la tradicional denominación de patrimonio histórico. Por su parte, Extremadura utiliza ambas denominaciones en su Ley 2/99, de 29 de marzo, del Patrimonio Histórico y Cultural; y la Rioja se refiere al concepto de “Patrimonio Cultural, Histórico y Artístico” en su Ley 7/2004, de 18 de octubre.

Andalucía, aunque usa los tradicionales términos de "patrimonio histórico", parte del concepto de "bien cultural" cuando define dicho patrimonio. Sobre el concepto amplio de patrimonio histórico: Barrero Rodríguez, C. (1990); (2009): 57 y ss; Parada Vázquez, R. (2007): 237-238; Sánchez Blanco, A. (2000); Mellado Ruiz, L. y Roca Fernández, Ma L. (2012): 253-254; Álvarez González, E.M. (2012): 24-27.

4 Ley Orgánica 2/07, de 19 de marzo, de reforma del Estatuto de Autonomía de Andalucía. Respecto al régimen jurídico del patrimonio histórico andaluz con anterioridad a la reforma estatutaria, vid, Barrero Rodríguez, C. (1996): 43 y ss. Un comentario al art. 68 del vigente Estatuto de Autonomía puede verse en Arana García, E (.2008): 657 y ss. 
pliamente citada en el mismo, hasta el punto de haberse calificado como un "Estatuto cultural"'s.

Como consecuencia de aquella atribución de competencias, el Estado ha aprobado la Ley del Patrimonio Histórico Español (LPHE), su Reglamento de desarrollo y la Ley sobre Restitución de Bienes Culturales que hayan salido de forma ilegal del territorio de un Estado miembro ${ }^{6}$. La LPHE otorga al Estado competencias sobre el patrimonio histórico español de conservación, promoción y fomento, protección frente a la exportación ilícita y la expoliación7, difusión internacional del conocimiento de dichos bienes y recuperación de los que hubiesen sido ilícitamente exportados (art. 2 de la $\mathrm{LPHE})^{8}$, correspondiendo a las CCAA la ejecución de lo dispuesto en dicha ley.

Por su parte, Andalucía cuenta con varias leyes en la materia entre las que destaca su norma marco, la Ley 14/07, de 26 de noviembre, de Patrimonio Histórico de Andalucía (LPHA) ${ }^{9}$. Esta disposición se encuentra pendiente de desarrollo reglamentario ${ }^{10}$, sin perjuicio de la aplicación del Reglamento de Protección y Fomento del Patrimonio Histórico de Andalucía" ${ }^{11}$ necesitado de una profunda reforma para su adaptación tanto a la LPHA como a algunas determinaciones procedimentales contenidas en la Ley 30/92, de 26 de noviembre, de Régimen Jurídico de las Administraciones públicas y del Procedimiento Administrativo Común (LRJAPAC). La LPHA reconoce en esta materia competencia exclusiva a la $\mathrm{CA}^{12}$, sin perjuicio de las competencias que correspondan al Estado o estén atribuidas a las Entidades locales (art. 3 de la LPHA). Veamos, pues, las competencias que se atribuyen a los Entes locales, como Administración más cercana a los bienes que integran aquel patrimonio.

5 Arana García, E. (2008): 658 y (2013): 23 y ss.

6 Ley 13/85, de 25 de junio, del Patrimonio Histórico Español; Real Decreto 111/86, de 10 de enero y Ley 36/94, de 23 de diciembre, sobre Restitución de Bienes Culturales que hayan salido de forma ilegal del territorio de un Estado miembro.

7 Sobre la competencia estatal sobre defensa contra la exportación y la controvertida competencia respecto a la lucha contra la expoliación, vid: Barrero Rodríguez, C. (2003): 346-347; Magán Perales, J.M. (2001); López Ramón, F. (1992):359 y ss.

8 Competencias que ejerce a través Ministerio de Educación, Cultura y Deporte, de la Dirección General de Bellas Artes y Bienes Culturales y de Archivos y Bibliotecas y de la Subdirección General de Protección del Patrimonio Histórico, según el Real Decreto 257/2012, de 27 de enero, por el que se desarrolla la estructura orgánica básica de dicho Ministerio (modificado por el Real Decreto 87/2013, de 8 de febrero).

9 AAVV (2010).

10 En este trabajo nos referiremos al Proyecto de Reglamento General de la LPHA, sometido a información pública por Resolución de 26 de septiembre de 2011, de la Dirección General de Bienes Culturales, y a la necesidad de introducir algunas reformas en el mismo.

11 Decreto 19/1995, de 7 de febrero, por el que se desarrollaba la anterior Ley 1/91, de 3 de julio de Patrimonio Histórico de Andalucía.

12 Esta competencia la ejerce a través de la Consejería de Cultura y Deporte creada por Decreto del Presidente 3/2012, de 5 de mayo, de la Vicepresidencia y sobre Reestructuración de Consejerías. La estructura orgánica de dicha Consejería se regula por Decreto 154/2012, de 5 de junio (modificado por Decreto 492/2012, de 18 de septiembre), el cual le atribuye competencias para la "promoción y fomento de la cultura en manifestaciones y expresiones tales como el patrimonio histórico, artístico, monumental, científico, industrial, arquitectónico, etnográfico y el patrimonio bibliográfico y documental” (art. 1.2, a). Para el ejercicio de sus competencias cuanta con varias Direcciones Generales, entre las que se encuentra la Dirección General de Bienes Culturales e Instituciones Museísticas. 


\section{B. El papel de los municipios en la protección del Patrimonio Histórico}

Junto al Estado y las CCAA, las Entidades locales también ostentan importantes competencias sobre protección del patrimonio histórico y cultural ${ }^{13}$. Tanto la legislación sectorial sobre patrimonio histórico como la normativa reguladora de la Administración local atribuyen a los municipios competencias propias sobre cooperación y colaboración en materia de patrimonio histórico y sobre aprobación del planeamiento urbanístico con destino a la protección del mismo.

Así, la LPHE se refiere a la necesaria cooperación que deben prestar los Ayuntamientos en la conservación y custodia del patrimonio histórico español comprendido en su término municipal, adoptando las medidas oportunas para evitar su deterioro, pérdida y destrucción. A la vez que deben notificar a la Administración competente cualquier amenaza, daño o perturbación que sufran dichos bienes, así como, las dificultades y necesidades que tengan para su cuidado (art. 7). En términos similares se pronuncia el art. 92.2, g) del Estatuto de Autonomía de Andalucía. Por su parte, el art. 25.2, apartados e) y $\mathrm{m}$ ) de la Ley Reguladora de Bases de Régimen Local reconoce competencias al municipio en los términos de la legislación del Estado y de las CCAA sobre "patrimonio histórico artístico" y "sobre actividades o instalaciones culturales y deportivas". Esta competencia la encontramos pormenorizada en el art. 9.11 de la Ley de Autonomía Local de Andalucía (LALA) ${ }^{14}$, que recoge como competencia propia de los municipios:

"la elaboración y aprobación de Catálogos urbanísticos y de planes de contenido de protección para la defensa, conservación y promoción del patrimonio histórico y artístico de su término municipal, siempre que estén incluidos en el planeamiento general de ordenación urbanística. En el caso de no estar incluidos en dicho plan, deberán contar con informe preceptivo y vinculante de la Consejería competente en materia de cultura".

Este artículo pone en conexión la materia de protección, conservación y promoción del patrimonio histórico de Andalucía con la competencia urbanística sobre "ordenación, gestión, ejecución y disciplina urbanística" que ostentan los municipios ${ }^{15}$. A través de esta competencia propia en materia urbanística, la LPHA encomienda a los municipios la función de colaborar activamente en la protección y conservación de los bienes integrantes del patrimonio histórico andaluz que radiquen en su término municipal, así como, realzar y difundir su valor cultural. Para la salvaguarda de dichos bienes, cuando su interés se encuentre amenazado, podrán adoptar, en caso de urgencia, las medidas cautelares necesarias sin perjuicio de cualquier otra función que legalmente tengan encomendada (art. 4.2 LPHA).

13 Vid, Gómez Barahona, A. (2001):47 y ss.

14 Ley 5/2010, de 11 de junio, de Autonomía Local de Andalucía.

15 Competencia reconocida en el art. 92.2.a) del Estatuto de Autonomía de Andalucía, art. 25.2.d) de la LBRL y art. 9.1 de la LALA. Sobre la importancia del urbanismo en la tutela del patrimonio histórico, vid, Barrero Rodríguez, C. (2007): 79 y ss. 
Además de las competencias propias que ostentan los municipios en materia de patrimonio histórico, éstos pueden ejercer competencias por delegación del Estado o de las CCAA (art. 27 LBRL). Al respecto, la LPHA prevé que el Consejo de Gobierno de la Junta de Andalucía, a través de Convenio con las Entidades locales andaluzas, podrá delegarle el ejercicio de competencias propias de la Administración de la Junta de Andalucía en materia de patrimonio histórico, dentro del marco establecido en el Estatuto de Autonomía de Andalucía (art. 4.3 LPHA). Sin perjuicio de esta facultad genérica de delegación de competencias que ostenta el Consejo de Gobierno, la LPHA regula la posibilidad -en ocasiones utilizada ${ }^{16}$ - de delegar en los municipios la competencia para autorizar obras y actuaciones sobre bienes inmuebles inscritos en el Catálogo General del Patrimonio Histórico Andaluz que no sean monumentos, jardines históricos o zonas arqueológicas ni estén comprendidos en su entorno o en el ámbito territorial de una actividad de interés etnológico, ni se trate de demoliciones, siempre que exista aprobado el correspondiente planeamiento urbanístico de protección ${ }^{17}$. Para que proceda aquella delegación se imponen una serie de condicionantes formales que refuerzan las competencias autonómicas ${ }^{18}$.

En la atribución de esas competencias propias y delegadas se hacen expresas alusiones a la necesidad de cooperación y colaboración municipal con otras Administraciones públicas. Así, si bien en todas las materias de competencia compartida entre el Estado y las CCAA se requiere de la colaboración y cooperación interadministrativa ${ }^{19}$, en pocas como en materia de patrimonio histórico, o en términos más amplios, patrimonio cultural, la necesidad de cooperación administrativa, en especial de los Entes locales, ha quedado tan claramente prevista ${ }^{20}$. Pero, por si ello fuese insuficiente, tanto la LPHE como la LPHA recogen un deber genérico de colaboración interadministrativa ${ }^{21}$ en el ejercicio de sus funciones y competencias de conservación, difusión y fomento del patrimonio histórico, a través de relaciones de plena comunicación, cooperación y asistencia mutua.

16 En el año 2011 se han aprobado delegaciones de competencias en el Ayuntamiento de Sevilla para autorizar obras y actuaciones que desarrollen Planes Especiales de Protección de varios Conjuntos Históricos, y en el Ayuntamiento de Carmona; como ya se hizo en el año 2010 respecto de municipios como Vélez Málaga, San Roque, Vejer de la Frontera, Utrera o Marchena. Al respecto, puede consultarse la página Web de la Consejería de Cultura y Deporte de la Junta de Andalucía: http://www.juntadeandalucia.es/ cultura/web/areas/bbcc/sites/consejeria/areas/bbcc/programas_planeamiento.

17 Art. 30.4 y art. 40 de la LPHA.

18 Así se requiere: solicitud de la delegación de competencias; remisión a la Consejería de Cultura y Deporte de una copia debidamente diligenciada del Plan urbanístico aprobado; contar con una Comisión técnica municipal que informe las obras o actuaciones, presidida por el Alcalde o concejal delegado en materia de urbanismo e integrada al menos, por personas con titulación para el ejercicio de la Arquitectura, la Arquitectura Técnica, la Arqueología y la Historia del Arte.

19 Vid, Gamero Casado, E, Fernández Ramos, S. (2012): 125 y ss.

20 Respecto a la variedad de políticas públicas que inciden en el patrimonio cultural y la necesidad de coordinación interadministrativa, vid, Ávila Rodríguez, C.Mª . (2007):.149-152, 158-159; Alegre Ávila, J.M. (1994). Sobre la necesaria colaboración y cooperación interadministrativa en materia de patrimonio histórico, puede consultarse la Sentencia de la Audiencia Nacional de 22 de septiembre de 1999 (Pte. Mangas González).

21 Art. 2.2 LPHE y art. 4.1 de la LPHA. 


\section{LOS INSTRUMENTOS DE PROTECCIÓN DEL PATRIMONIO CULTURAL DE LAS CCAA: EL CATÁLOGO GENERAL DEL PATRIMONIO HISTÓRICO ANDALUZ}

En las legislaciones de patrimonio histórico autonómicas se observa una diversidad conceptual en cuanto a los mecanismos de protección de dichos bienes ${ }^{22}$, que contrasta con las escasas divergencias en cuanto al régimen jurídico aplicable ${ }^{23}$, que en la mayoría de los supuestos solo constituyen concreciones y desarrollos de las previsiones ya apuntadas en la LPHE.

Por lo que respecta a Andalucía, la LPHA ha regulado en su Título I dos instrumentos básicos para la protección del patrimonio histórico: el Catálogo General del Patrimonio Histórico Andaluz y el Inventario de Bienes Reconocidos del Patrimonio Histórico Andaluz.

El Catálogo General del Patrimonio Histórico Andaluz (CGPHA), como técnica principal para la protección de dicho patrimonio, sirve para la tutela o protección de los bienes que en el mismo se incluyen y para la difusión de su conocimiento ${ }^{24}$. La competencia para su elaboración, conservación y difusión la ostenta la Consejería competente en materia de patrimonio histórico ${ }^{25}$, en la actualidad la Consejería de Cultura y Deporte, que la ejerce a través de la Dirección General de Bienes Culturales e Instituciones Museísticas ${ }^{26}$.

22 Sobre los regímenes de protección de los bienes culturales, vid: Barrero Rodríguez, C. (2003): 341; López Bravo, C. (1999): 11 y ss; Fernández de Gatta Sánchez, D. (1999): 33 y ss.

23 Del análisis del régimen de protección de los bienes contenido en las legislaciones de patrimonio histórico o cultural autonómicas podemos concluir:

a) La mayoría de ellas recogen tres categorías de protección referidas a los bienes de interés cultural (BIC), bienes inventariados o catalogados, donde se incluyen los bienes inmuebles, y otros bienes dignos de protección.

b) Comunidades Autónomas como Islas Baleares, Madrid, Extremadura, País Vasco, Murcia, Cataluña, Cantabria o Andalucía cuentan con un Registro, Catálogo o Inventario diferenciado para referenciar a los BIC, bienes catalogados o bienes inventariados; mientras que otras han creado un documento o registro que aglutina a todos los bienes del patrimonio histórico de la Comunidad, tal es el caso de Galicia, La Rioja, la Comunidad Valenciana o Navarra.

c) Destaca la Comunidad Autónoma de Canarias que recoge hasta seis instrumentos de protección (Registro de BIC, Inventarios de Bienes Muebles, Catálogos arquitectónicos municipales, Cartas etnológicas municipales, Cartas arqueológicas municipales y cartas paleontológicas municipales).

d) Algunas CCAA al efectuar la clasificación de los instrumentos de protección de sus bienes contienen referencias al ámbito territorial del interés histórico o cultural de los bienes. Así, Cataluña se refiere a los bienes culturales catalogados o de interés local; Canarias alude a los Catálogos arquitectónicos municipales y a las Cartas etnológicas, arqueológicas y paleontológicas municipales; o La Rioja que se refiere a los bienes culturales de interés regional. Y ciertamente lo que las CCAA regulan es un régimen de protección específico referido: a los BIC, sean de relevancia nacional o regional; a otros bienes catalogados o inventariados por el especial interés regional y a los bienes catalogados por los municipios por su interés local.

24 Puede consultarse en: http://www.juntadeandalucia.es/cultura/web/areas/bbcc/catalogo

25 Art. 6.2 LPHA.

26 Art. 8 del Decreto 154/2012, de 5 de junio, que regula la estructura orgánica básica de la Conse$50 \quad$ jería de Cultura y Deporte. 
Partiendo de la regulación que realiza la LPHA vamos a analizar el contenido del Catálogo y el procedimiento de inscripción y sus efectos.

\section{A. Contenido}

El Catálogo General del Patrimonio Histórico de Andalucía (CGPHA) comprenderá tres tipos de bienes: a) los bienes de interés cultural (BIC); b) los bienes de catalogación general; y c) los incluidos en el Inventario General de Bienes Muebles del patrimonio histórico español (art. 7 LPHA) ${ }^{27}$.

\section{a) Los BIC: procedimiento de declaración y necesidad de algunas adaptaciones}

La calificación de un bien como BIC se aplica de forma principal a los bienes inmuebles, pero también determinados bienes muebles pueden alcanzar esta categorización ${ }^{28}$. Así, la LPHA ${ }^{29}$, además de considerar los BIC como bienes integrantes del $\mathrm{CGPHA}^{30}$, prevé que formarán parte del mismo aquellos bienes inmuebles o muebles declarados BIC ubicados en Andalucía o que tengan tal consideración según lo previsto en la LPHE, así como, aquellos bienes que de forma específica venían inscritos en el Catálogo General del Patrimonio Histórico Andaluz creado por la anterior Ley 1/91, de 3 de julio, de Patrimonio Histórico de Andalucía ${ }^{31}$.

\section{- Procedimiento de declaración}

Los bienes de interés cultural (BIC), como bienes sujetos a una singular protección y tutela, encuentran su regulación en la Ley de Patrimonio Histórico Español(LPHE) que

27 La Estadística del Patrimonio Histórico de Andalucía recoge un total de 22.366 bienes muebles inscritos en el Catálogo General del Patrimonio de Andalucía y 3978 bienes inmuebles inscritos en dicha Catálogo, tomando como referencia el año 2011. Estos datos pueden consultarse en: http://www.juntadeandalucia.es/cultura/web/html/sites/consejeria/estadistica/Galerias/Adjuntos/estadistica/patrimonio_ historico/2011/20120306/inmuebles11.pdf

28 Parada Vázquez, R. (2007): 236, 248-251.

29 D.A.Segunda, apdo $2^{\circ}$ y D.A.Tercera de la LPHA.

30 La LPHA amplía los conceptos por los que se podrá inscribir un bien inmueble declarado BIC en el Catálogo General en relación a la inscripción de dichos bienes en el Registro General de la Administración del Estado. Así, podrán figurar como: monumentos, conjuntos históricos, jardines históricos, sitios históricos, zonas arqueológicas, lugares de interés etnológico, lugares de interés industrial y zonas patrimoniales (art. 25 LPHA).

31 Hay que tener en cuenta que la Disposición Transitoria de la Ley 1/91, de 3 de julio del Patrimonio Histórico de Andalucía establecía un plazo de 3 años desde su entrada en vigor para la resolución de los expedientes que se estuviesen tramitando para la declaración de un bien como BIC al amparo de la LPHE. Transcurrido ese plazo, la Jurisprudencia del Tribunal Supremo entiende que se produce la caducidad de dichos expedientes, aún cuando se hubiese iniciado su tramitación antes de la entrada en vigor de la LPHE; en este sentido, la STS de 22 de mayo de 2012 (Pte. Martí García), en la que se reitera la doctrina sentada en la Sentencia de 25 de septiembre de 2008 (Pte. Fernández Pérez). En dicha sentencia se declara la caducidad de un expediente de declaración de BIC en el que desde su incoación -en 1983- hasta su resolución han transcurrido 24 años. 
se refiere al procedimiento para su declaración como tal ${ }^{32}$; declaración que puede efectuarse por ley 33 o mediante "Real Decreto" de forma individualizada (art. 9.1 LPHE). La STC 17/91, de 31 de enero, se ha referido a esa distribución de competencias entre el Estado y las CCAA en cuanto a la declaración de BIC, atribuyendo dicha competencia a las CCAA y de forma muy limitada al Estado ${ }^{34}$. En este sentido, la declaración de un bien como BIC corresponde al Estado mediante Real Decreto cuando se refiera a bienes del patrimonio histórico español adscritos a servicios públicos por la Administración del Estado o formen parte del Patrimonio Nacional. En el resto de los supuestos dicha competencia la ostentan las CCAA -se entiende que mediante Decreto- y siguiendo el procedimiento que se determine en su correspondiente normativa ${ }^{35}$.

Sin embargo, la LPHA no ha regulado un procedimiento específico para la declaración de interés cultural de un bien, por lo que hemos de estar supletoriamente a las previsiones genéricas que establece el art. 9 de la LPHE y los arts.12 a 20 del Real Decreto 111/86, de 10 de enero, de desarrollo parcial de la $\mathrm{LPHE}^{36}$.

\section{- Necesidad de algunas adaptaciones procedimentales}

Aunque la normativa estatal analizada, aplicable de forma supletoria a Andalucía, no exige el trámite de audiencia a los interesados en el procedimiento de declaración de un BIC, dicho trámite viene siendo exigido por la Jurisprudencia del Tribunal Supremo en una interpretación conjunta de las normas relativas al procedimiento para realizar la declaración de BIC y la normativa andaluza que regula la inscripción de dichos bienes en el Catálogo General del Patrimonio Histórico Andaluz. Y ello por cuanto la incoación del expediente de declaración como BIC conlleva la anotación preventiva en el citado Catálogo y la aplicación de su régimen de protección 37 .

32 Un estudio sobre las demoras en la tramitación de expedientes de declaración de bienes de interés cultural a través del análisis de las quejas presentadas ante el Defensor del Pueblo Andaluz puede verse en Ávila Rodríguez, C. Ma (2007): 179-181,196 y ss.

33 La D.A.Primera de la LPHE declara que son BIC los bienes que con anterioridad hayan sido declarados históricos-artísticos o incluidos en el Inventario del Patrimonio Artístico y Arqueológico de España; la misma consideración se atribuye a los bienes a que se refieren los Decretos de 22 de abril de 1949, 571/1963 y 449/1973, según la D.A.Segunda de la LPHA.

34 Sobre la competencia autonómica para la declaración de BIC, entre otras: la STS de 15 de octubre de 2008 (Pte. Martínez-Vares García) y STS de 23 de marzo de 2011 (Pte. Martínez-Vares García).

35 Así, el art. 11.2 del Real Decreto 111/86, de 10 de enero, de desarrollo parcial de la LPHE -modificado con posterioridad a la citada sentencia constitucional- dispone que "corresponde a las CCAA la declaración de interés cultural de los restantes bienes del patrimonio histórico español, cuya tramitación se regirá por su propia normativa".

36 El art. 9 de la LPHE, tras exigir expediente administrativo, prevé que en el mismo conste informe favorable de las instituciones consultivas de las CCAA en la materia, entendiéndose dicho informe favorable a la declaración de interés cultural si no se hubiese emitido en el plazo de tres meses desde su solicitud. Se requiere además de un trámite de información pública y de audiencia al Ayuntamiento interesado en caso de que el expediente se refiera a un bien inmueble.

37 vid, STS de 23 de marzo de 2011; Pte. Martínez-Varas García. 
Por otra parte, aunque el art. 9.3 de la LPHE exige la denuncia de la mora para que se produzca la caducidad del expediente de declaración de un BIC, es reiterada la Jurisprudencia más reciente del Tribunal Supremo que sostiene que en la actualidad la caducidad se produce en los términos que dispone el art. 44.2 de la LRJAPAC, que resulta aplicable a las CCAA y no según lo dispuesto en la legislación sectorial sobre patrimonio histórico ${ }^{38}$.

\section{b) Los bienes de catalogación general}

El segundo tipo de bienes que integran el CGPHA lo constituyen los bienes de catalogación general. A estos bienes se refiere en varias ocasiones la LPHA a lo largo de su articulado tanto cuando alude a los bienes inmuebles como a bienes muebles, para identificarlos con aquellos bienes que no gozan de la especial protección propia de los BIC; aunque no incluye su definición. Más clarificadora resulta al respecto las Disposiciones Adicionales Segunda, apartado $1^{\circ}$, Quinta, apartado $2^{\circ}$ y Sexta, apartado $2^{\circ}$, que consideran bienes de catalogación general:

- Los bienes inscritos con carácter genérico en el CGPHA con anterioridad a la entrada en vigor de la Ley ${ }^{39}$.

- Los inmuebles del patrimonio histórico andaluz y los elementos de los mismos (de piedra, yeso, madera, forja, fundición...) pertenecientes a la Iglesia Católica o que se encuentren en posesión de la Administración de la Junta de Andalucía, las Entidades locales y las Universidades ${ }^{40}$.

\section{c) Los bienes incluidos en el Inventario General de Bienes Muebles}

Por último, el CGPHA se integra por los bienes incluidos en el Inventario General de Bienes Muebles del Patrimonio Histórico Español. Dicho Inventario se compone por los bienes muebles del patrimonio histórico español de singular relevancia no declarados BIC (art. 26.1 LPHE) y su organización y funcionamiento se regula por el Reglamento de desarrollo de la $\mathrm{LPHE}^{41}$. En la actualidad se adscribe a la Dirección General de Bellas Artes y Bienes Culturales y de Archivos y Bibliotecas del Ministerio de Educación, Cultura y Deporte, a través de la Subdirección General de Protección

38 Vid, la STS de 3 de julio de 2012, Pte. Enríquez Sánchez, fj. $4^{\circ}$ y $5^{\circ}$ y sentencias anteriores como la de 27 de marzo, 24 de mayo y 4 de abril de 2012, citadas por aquella.

39 Hemos de tener en cuenta que la anterior Ley 1/91, de 3 de julio, de Patrimonio Histórico de Andalucía permitía la inscripción en el Catálogo General de forma genérica o específica (arts. 8 y 11 de la Ley 1/91).

40 Mientras que respecto de los citados inmuebles la inscripción en el Catálogo General se realiza ex lege, los primeros requieren la incoación del correspondiente procedimiento, según se deduce del art. 9 de la LPHA.

41 Art. 26.5 LPHE y arts.24 y ss del Real Decreto 111/86, de 10 de enero, de desarrollo parcial de dicha Ley. 
del Patrimonio Histórico ${ }^{42}$. La confección de dicho Inventario corresponde a la Administración del Estado en colaboración con las CCAA ${ }^{43}$.

La LPHA dispone que quedan inscritos en el Catálogo General como bienes incluidos en el Inventario General de Bienes Muebles del Patrimonio Histórico Español los bienes muebles del patrimonio histórico andaluz de interés artístico, histórico, arqueológico, etnológico, documental, bibliográfico, científico o industrial cuando así hayan sido reconocidos en el Inventario de Bienes Muebles de la Iglesia Católica ${ }^{44}$, y los que se encuentren en posesión de la Junta de Andalucía, Entidades Locales y Universidades ${ }^{45}$.

\section{B. El procedimiento de inscripción en el Catálogo General y efectos ${ }^{46}$}

\section{a) Inicio}

La inscripción de los bienes citados se efectúa por ministerio de la ley o de oficio por la Consejería competente en materia de patrimonio histórico. El primer supuesto se aplica respecto de los bienes a que se refiere la Disposición Adicional Tercera, Quinta y Sexta ${ }^{47}$ (los bienes muebles e inmuebles de la Iglesia Católica; los que se encuentren en posesión de la Junta de Andalucía, Entidades locales y Universidades, así como, los BIC que hayan sido declarados como tal de conformidad con la LPHE siempre que estén ubicados en Andalucía).

Hemos de entender que el resto de bienes susceptibles de integrar el patrimonio histórico de Andalucía, respecto de los que no proceda la inscripción por ministerio de la ley, requieren de la incoación del procedimiento de inscripción, el cual se inicia de oficio por la Consejería de Cultura y Deporte ${ }^{48}$. No obstante, dicha incoación puede solicitarse por cualquier persona física o jurídica de forma razonada. Ello dará lugar al

42 El art. 24.1 del Real Decreto 111/86, de 10 de enero, Reglamento de desarrollo parcial de la LPHE y Real Decreto 257/2012, de 27 de enero, por el que se desarrolla la estructura orgánica básica del Ministerio de Educación, Cultura y Deporte.

43 Dicha inclusión se rige por las normas contenidas en el Capítulo IV, del Título II, del Real Decreto 111/86, de 10 de enero (arts.30 y ss). Sobre la competencia autonómica para la inclusión de bienes en el Inventario General de Bienes Muebles, vid, Barrero Rodríquez, C. (2003): 340.

44 Sobre el Inventario de bienes muebles de la Iglesia Católica, vid, Pazos Bernal, $M^{\mathrm{a}} \mathrm{A}$. (2010):113-15.

45 DA Quinta, apartado $1^{\circ}$, DA Sexta, apartado $1^{\circ}$ de la LPHA.

46 El procedimiento de inscripción se regula en los art. 9 y ss de la LPHA y, en lo que no se oponga a la misma, en el Real Decreto 19/95, de 7 de febrero, Reglamento de Protección y Fomento del Patrimonio Histórico de Andalucía, desarrollo de la anterior Ley de Patrimonio Histórico de Andalucía de 1991. Al respecto de dicho procedimiento, entre otros, Ortiz Sánchez, M. (2011):113 y ss.

47 Art. 9 de la LPHA.

48 El art. 9.1 del Real Decreto 19/95, de 7 de febrero, atribuye esa competencia al Director General de Bienes Culturales, hoy Director General de Bienes Culturales e Instituciones Museísticas; al igual que el art. 5.1 del Decreto 4/1993, de 26 de enero, por el que se aprueba el Reglamento de Organización Administrativa del Patrimonio Histórico de Andalucía, modificado en 1995 y más recientemente por Decreto 379/2009, de 1 de diciembre. Sin embargo, por Resolución de 15 de julio de 2008 se delega en las personas titulares de las Delegaciones Provinciales de la Consejería de Cultura determinadas competencias en materia de patrimonio his54 tórico, entre ellas, “los actos de instrucción de los procedimientos de inscripción o de cancelación en 
inicio de un procedimiento que podrá terminar con resolución expresa que acuerde o deniegue la incoación del procedimiento de inscripción, o bien, con resolución presunta desestimatoria transcurridos tres meses desde la presentación de la solicitud sin que se haya resuelto y notificado el citado procedimiento ${ }^{49}$. El cómputo de esos tres meses, que la LPHA referencia en la "presentación de la solicitud", hay que entender que se produce desde la fecha en que la solicitud haya tenido entrada en el Registro del órgano competente para su tramitación como señala el art. 42.3.b) de la LRJAPAC.

La resolución que acuerde la incoación del procedimiento debe estar motiva$\mathrm{da}^{50}$, produce efectos cautelare $\mathrm{s}^{51}$ y puede ordenar la redacción de instrucciones particulares aplicables respecto de los $\mathrm{BIC}^{52}$, además, será objeto de publicación en el BOJA, sin perjuicio de su notificación a los interesados en el procedimiento ${ }^{53}$.

\section{b) Tramitación}

La LPHA recoge determinaciones específicas según que la inscripción vaya referida a BIC, bienes de catalogación general o bienes del Inventario General de Bienes Muebles, exigiendo más trámites procedimentales respecto de la inscripción de bienes inmuebles o del patrimonio etnológico que respecto a los bienes muebles ${ }^{54}$. Así, en la inscripción de bienes muebles, cualquiera que sea su categorización (BIC, bienes catalogados...), bastará con la audiencia a los particulares directamente afectados ${ }^{55}$, mientras que tratándose de bienes inmuebles del patrimonio histórico andaluz su inscripción en el Catálogo General requiere someterse a la participación ciudadana y al municipio donde radiquen ${ }^{56}$.

49 Art. 9.1 LPHA.

50 Así lo dispone el art. 10 del Real Decreto 19/95, de 7 de febrero, que se refería al contenido que tenía que tener esta resolución según que se tratase de una inscripción específica o genérica, distinción que no realiza la vigente LPHA.

51 Así, aquella resolución conllevará como medida cautelar la anotación preventiva del bien en el CGPHA (art. 9.2 LPHA).

52 Cuando se ordene la redacción de las citadas instrucciones particulares, las mismas deberán obrar en el expediente antes de que se efectúe el trámite de información pública y de audiencia; incluso cuando fuese necesario aquella resolución de incoación incluirá unas instrucciones provisionales como medida caute$\operatorname{lar}$ (art. 11.2 LPHA). El art. 16 del Real Decreto 19/95, de 7 de febrero, determina el contenido de las instrucciones particulares, aunque las refiere a los bienes de inscripción específica. Las mismas deberán indicar: las actividades, elementos y materiales que pueden ser aceptados y los expresamente prohibidos; tipo de obras o actuaciones sobre el bien catalogado o su entorno para las que no se requiere autorización previa..., entre otras.

Respecto a la seguridad jurídica que proporcionan estas instrucciones particulares, vid, Barrero Rodríguez, C. (1996): 43 y ss.

53 El art. 11 del Real Decreto 19/95, de 7 de febrero, se refiere a dicha notificación.

54 Art. 9, apartados $3^{\circ}, 4^{\circ}$ y $5^{\circ}$ LPHA.

55 El trámite de audiencia a los interesados se realizará por un plazo no inferior a 10 días ni superior a 15 días, debiendo efectuarse con carácter previo a la redacción de la propuesta de resolución (Art. 84 de la LRJAPAC y art. 12.5 del Real Decreto 19/95, de 7 de febrero).

56 El trámite de información pública, en los casos en que resulta preceptivo, se anunciará en el BOJA y se prolongará por espacio mínimo de un mes. El mismo plazo se prevé para el trámite de audiencia a municipios y organismos públicos afectados. Para el desarrollo de este trámite se exige que entre la do- 
Durante la tramitación del procedimiento de inscripción de los BIC, bienes de catalogación general y de bienes del Inventario General de Bienes Muebles se requiere informe favorable de alguno de los órganos consultivos a que se refiere la Ley (Consejo Andaluz de Patrimonio Histórico, Comisiones Andaluzas de Bienes Culturales... $)^{57}$.

\section{c) Resolución y recursos}

La competencia para dictar la resolución del procedimiento de inscripción en el Catálogo ${ }^{8}$ la ostenta el Consejo de Gobierno tratándose de BIC, la Consejería competente en materia de patrimonio histórico respecto de bienes de catalogación general; y el titular de la Dirección General de Bienes Culturales e Instituciones Museísticas en cuanto a bienes incluidos en el Inventario General de Bienes Muebles del Patrimonio Histórico Español.

El art. 13 del Real Decreto 19/95, de 7 de febrero se refiere al contenido, notificación y publicación de la resolución de inscripción en el Catálogo General59. Resolución que según la Jurisprudencia del Tribunal Supremo tiene carácter reglado ${ }^{60}$.

Junto a la terminación normal del procedimiento mediante resolución expresa cabe la caducidad como forma anormal de terminación ${ }^{61}$. La misma se produce por el transcurso de 18 meses $^{62}$, desde la fecha de incoación, sin que se haya dictado y notificado la resolución ${ }^{63}$.

cumentación figure el proyecto de instrucciones particulares cuando se trate de la inscripción de un bien inmueble (Art. 12.1, 2 del Real Decreto 19/95, de 7 de febrero). LPHA).

57 El citado informe se entenderá favorable si no se emite en el plazo de dos meses ( Art. 9.6 de la

58 Art. 9.7 LPHA.

59 La resolución será objeto de publicación en el BOJA.

60 La Sentencia de 21 de abril de 2010 mantiene el carácter reglado de la resolución de catalogación; y ello, porque "si hay elementos protegibles, la Administración necesariamente debe conferir al inmueble el nivel o grado de protección idóneo y adecuado a sus características, de forma análoga o equivalente a lo que sucede con el suelo de especial protección", por ello considera ilegal la degradación en la protección de un bien catalogado por motivos de oportunidad.

61 Regulada en el art. 9.8 de la LPHA.

62 Respecto de este plazo de caducidad hemos de tener en cuenta el Decreto-Ley 1/2009, de 24 de febrero, por el que se adoptan medidas urgentes de carácter administrativo, cuyo art. 4 modifica la Ley 9/01, de 12 de julio, por la que se establece el sentido del silencio administrativo y los plazos de determinados procedimientos como garantías procedimentales para los ciudadanos. Así, respecto del procedimiento de inscripción y cancelación de los BIC considerados monumentos y jardines históricos se mantiene el plazo de 18 meses para su resolución y notificación; mientras que para los restantes BIC el plazo se reduce a 12 meses, al igual que para la inscripción y cancelación de Bienes de Catalogación General de bienes inmuebles y actividades de interés etnológico.

63 Como hemos analizado, la LPHA ha eliminado la posibilidad de iniciar el procedimiento a instancia de parte, al establecer en su art. 9.1 que "se incoará de oficio", sin perjuicio de admitir la solicitud de incoación a instancia de persona física o jurídica. En consecuencia, la ausencia de resolución y notificación en el plazo máximo establecido produce la caducidad del procedimiento. No se admite, pues, la desestimación presunta de la solicitud como recoge el art. 14 del Real Decreto 19/95, de 7 de febrero, que además de establecer un plazo máximo de resolución de 24 meses, superior al actualmente vigente, admitía junto a la posible caducidad del procedimiento, la desestimación presunta, según que su forma de inicio fuese de oficio o a instancia de parte. 
Por lo que respecta al régimen de recursos administrativos que proceden contra la resolución del procedimiento de inscripción en el Catálogo General, tratándose de resoluciones del Consejo de Gobierno o del Consejero competente se considera que las mismas agotan la vía administrativa, siendo recurribles mediante recurso potestativo de reposición; mientras que en el caso de tratarse de una resolución dictada por el Director General de Bienes Culturales y Actividades Museísticas, podrá ser recurrida mediante recurso de alzada. Ello, sin perjuicio, en ambos casos, de la posibilidad de que una vez agotada la vía administrativa pueda recurrirse la resolución mediante recurso contencioso-administrativo ${ }^{64}$.

\section{d) Efectos de la inscripción}

La inscripción de bienes en el CGPHA conlleva una serie de obligaciones y limitaciones para los propietarios, poseedores y titulares de derechos sobre los mismos, a los que nos referiremos más adelante. Pero además, implica su regulación por lo dispuesto en la LPHA para cada categoría de bienes inscritos, suponiendo ello una singular protección y tutela para los BIC, así como, la aplicación del régimen jurídico previsto en la LPHE para los bienes catalogados como integrantes del Inventario General de Bienes Muebles del Patrimonio Histórico Español. Ese importante régimen de protección que deriva de la inscripción de un bien en el Catálogo General se despliega con carácter provisional desde su anotación preventiva que se produce con la Resolución de incoación del procedimiento ${ }^{65}$.

Por otro lado, la LPHA recoge la necesidad de que determinados bienes inscritos en el Catálogo General queden inscritos en el correspondiente Registro o Inventario de la Administración General del Estado ${ }^{66}$, y/o en el Registro de la Propiedad ${ }^{67}$.

\section{EL INVENTARIO DE BIENES RECONOCIDOS DEL PATRIMONIO HISTÓRICO ANDALUZ}

\section{A. La inscripción de bienes inmuebles y actividades de interés etnológico y la relevante función de los Catálogos urbanísticos municipales}

La LPHA crea junto al CGPHA otro instrumento para la protección de dicho patrimonio, el Inventario de Bienes Reconocidos del Patrimonio Histórico Andaluz

64 Así hay que deducirlo de lo dispuesto en el art. 112 de la Ley 9/07, de 22 de octubre, de la Administración de la Junta de Andalucía; del art. 9.7 de la LPHA y de los arts.107 y ss de la LRJAPAC.

65 Art. 8.d) y art. 9.2 LPHA.

66 Así, las inscripciones y anotaciones preventivas de BIC y de bienes del Inventario de Bienes Muebles del Patrimonio Histórico Español se comunicarán a la Administración General del Estado para su constancia en el Registro General y en el Inventario General de Bienes Muebles no declarados BIC, respectivamente (art. 9.9 LPHA)

67 Al mismo tiempo, cuando los bienes inscritos en el Catálogo General sean bienes inmuebles, la Consejería competente en materia de patrimonio histórico instará su inclusión gratuita en el Registro de la Propiedad. Para ello será título suficiente la certificación administrativa expedida por la citada Consejería en la que se transcriba la inscripción en el CGPHA (art. 12 LPHA). 
$(\text { IBR })^{68}$. Dicho Inventario tiene por objeto facilitar la identificación de los bienes que integran dicho patrimonio, y del mismo no forman parte los bienes que se inscriban en el CGPHA. La formación, conservación y difusión de este Inventario corresponde a la Consejería de Cultura y Deporte.

¿Qué bienes forman parte de este Inventario? Dos tipos de bienes resultan inscribibles:

- Los bienes inmuebles y los espacios vinculados a actividades de interés etnológico a los que se les reconozca como integrantes del patrimonio histórico andaluz por resolución de la Dirección General de Bienes Culturales e Instituciones Museísticas. Dicha resolución se publica en el BOJA y debe contener al menos la identificación y localización de los bienes reconocidos ${ }^{69}$.

- Los bienes inmuebles en los que concurra algún valor artístico, histórico, arqueológico, etnológico, científico o industrial para la Comunidad Autónoma y los espacios vinculados a actividades de interés etnológico contenidos en los Catálogos urbanísticos, una vez que hayan sido incluidos en el Registro administrativo previsto en la normativa urbanística ${ }^{70}$. A tal efecto, la Consejería responsable de tal registro comunicará a la Consejería de Cultura y Deporte las inscripciones que se produzcan en el mismo.

Así pues, sólo los bienes inmuebles y espacios vinculados a actividades de interés etnológico pueden formar parte de este Inventario. En el primer supuesto expuesto, la decisión de su inclusión se deja en manos de la Consejería competente en materia de patrimonio histórico andaluz; mientras que en el segundo caso, la integración de dichos bienes en el Inventario depende de dos hechos previos, que figuren en un Catálogo urbanístico y su posterior reflejo en el correspondiente registro administrativo, actuaciones en las que intervienen los órganos con competencias en materia urbanística de la Administración local y de la Comunidad Autónoma de Andalucía. Para ello, cuando los municipios elaboren sus Catálogos urbanísticos vienen obligados por la LPHA (art. 13.3) a incluir en los mismos aquellos bienes inmuebles y espacios del Inventario que hayan sido reconocidos por Resolución de la Dirección General de Bienes Culturales e Instituciones Museísticas y que radiquen en su término municipal71.

68 Art. 13 LPHA.

69 En este sentido, vid, la Resolución de 7 de septiembre de 2009, de la Dirección General de Bienes Culturales, por la que se incluyen en el Inventario de Bienes Reconocidos los bienes inmuebles de la arquitectura contemporánea, sitos en la provincia de Cádiz, que se relacionan en su Anexo. Según la Resolución el denominador común de estos bienes es pertenecer a la arquitectura contemporánea de todo el Siglo XX, incluyendo tanto inmuebles acotados, como espacios donde tienen cabida una amalgama de edificios de usos, formas y materiales diversos.

70 Respeto al papel del planeamiento urbanístico en la protección del patrimonio cultural, entre otros: Sánchez Goyanes, E. (2001): 61 y ss.

71 Art. 13.3 LPHA. A tal efecto, el Proyecto de Reglamento General de desarrollo de la LPHA (sometido a información pública por Resolución de 26 de septiembre de 2011 de la Dirección general de Bienes Culturales) prevé que los Ayuntamientos dirijan consulta a la Dirección General competente en materia de patrimonio histórico cuando procedan a la redacción, modificación, actualización o revisión de sus Catálogos urbanísticos, para que aquella les informe de los bienes inmuebles y espacios vinculados a actividades 
Los Catálogos urbanísticos se constituyen como uno de los instrumentos de planeamiento, junto al planeamiento general y los planes de desarrollo ${ }^{72}$. Regulados en el art. 16 de la Ley de Ordenación Urbanística de Andalucía (LOUA), tienen por objeto complementar las determinaciones de los instrumentos de planeamiento relativas a la conservación, protección y mejora del patrimonio urbanístico, arquitectónico, histórico, cultural, natural y paisajístico. A tal efecto, deben contener la relación detallada y la identificación de los bienes y espacios que por reunir aquellos valores deban de ser objeto de una especial protección. La competencia para su aprobación corresponde a los municipios si se trata de Catálogos de ámbito municipal y a la Consejería competente en materia de urbanismo cuando tenga incidencia o interés supramunicipal73.

Todos los bienes y espacios contenidos en los Catálogos aprobados se deben incluir por la Consejería competente en materia de urbanismo en el Registro administrativo de instrumentos de planeamiento a que se refiere el art. 40 de la LOUA ${ }^{74}$. Registro que deben llevar tanto los Ayuntamientos como la Consejería competente en materia de urbanismo, según quien ostente la competencia para la aprobación de los mismos. Así, pues, en el Registro de instrumentos de planeamiento aprobados por la Consejería competente deberán figurar los bienes y espacios catalogados por los municipios como de especial interés arquitectónico, histórico, cultural, natural..., así como, los que hayan sido catalogados por la citada Consejería y que tengan una incidencia o interés supramunicipal75.

En definitiva, la conformación del Inventario de Bienes Reconocidos queda en manos de los municipios mediante la aprobación de los Catálogos urbanísticos municipales, de la Consejería competente en materia de urbanismo a través de los Catálogos urbanísticos con incidencia o interés supramunicipal de que disponga; y de forma más directa, queda a disposición de la Dirección General de Bienes Culturales e Instituciones Museísticas como órgano con competencias en patrimonio histórico andaluz.

La creación del IBR garantiza que la consulta de estos bienes inmuebles y espacios reconocidos no se encuentre dispersa.

\section{B. La ausencia de determinación del procedimiento de inclusión y exclusión de Bienes en el IBR}

La formación, conservación y difusión de dicho Inventario es competencia de la Consejería de Cultura y Deporte (art. 13.1 LPHA). ¿Pero cual es el procedimiento de

de interés etnológico situados en su término municipal que hayan sido incluidos en el Inventario de Bienes Reconocidos en virtud de resolución expresa (art. 28.2 del Proyecto).

72 Art. 7.1 de la Ley 7/02, de 17 de diciembre, de Ordenación Urbanística de Andalucía. Al respecto, Becerra García, J.M (2010): 31 y ss; Vera Jurado, D.J. y Ildefonso Huertas, R. (2003): 76.

73 Art. 31.1.B, e) y 2.B.b) de la LOUA.

74 Según dispone el art. 16.3 de la LOUA.

75 El Proyecto de Reglamento General de la LPHA ha limitado, sin apoyo legal, los bienes inmuebles y espacios de naturaleza etnológica que pueden ser incluidos en el Inventario, al limitarlos exclusivamente a los que "se hallen incluidos en Catálogos urbanísticos de los municipios de la Comunidad Autónoma de Andalucía" (art. 25.2 del Proyecto). 
inclusión de los bienes inmuebles y espacios vinculados a actividades de carácter etnológico en el Inventario? La LPHA no regula el procedimiento para la formación del Inventario; a lo que se suma la falta de desarrollo reglamentario de la LPHA de 2007 y su no previsión en la anterior regulación normativa ${ }^{76}$.

Ello ha originado que el Proyecto de Reglamento General de la LPHA dedique su Título II, Capítulo II al Inventario de Bienes Reconocidos del Patrimonio Histórico Andaluz. Al respecto regula el procedimiento de inclusión de bienes inmuebles y espacios vinculados a actividades de interés etnológico mediante resolución de la Dirección General competente en materia de patrimonio histórico (art. 26) y el procedimiento de inclusión de dichos bienes y espacios cuando figuren en Catálogos urbanísticos (art. 27); aunque con algunas imprecisiones procedimentales. En el primer supuesto, el procedimiento puede iniciarse de oficio o a instancia de parte ${ }^{77}$. En este caso, cualquier persona física o jurídica podrá instar dicha inclusión mediante solicitud razonada en la que se identifique de forma precisa el bien y en la que se debe acreditar la concurrencia del interés histórico, artístico, cultural..., o sea, los valores a que se refiere el art. 2 LPHA. El plazo para resolver el procedimiento será de tres meses, transcurrido el cual sin haberse dictado y notificado la correspondiente resolución del procedimiento, la misma se entenderá desestima$\mathrm{da}^{78}$, o sea, se considera denegada la inclusión del bien o espacio en el Inventario ${ }^{79}$. La Resolución se publicará en el BOJA y se notificará al Ayuntamiento correspondiente para que proceda a la inclusión del bien o espacio en el Catálogo urbanístico del municipio.

Por lo que respecta al procedimiento de inscripción de bienes inmuebles o espacios vinculados a actividades etnológicas, el art. 27 del Proyecto de Reglamento General de la LPHA determina su inclusión en el Inventario de todos aquellos que se hallen contenidos en los Catálogos urbanísticos e inscritos en el Registro administrativo que, a estos efectos, prevé la legislación urbanística de Andalucía ${ }^{80}$.

76 Ello no ha impedido la aprobación de la Resolución de 7 de septiembre de 2009 de la Dirección General de Bienes Culturales, por la que se incluyen en el Inventario de Bienes Reconocidos del Patrimonio Histórico Andaluz los bienes inmuebles de la arquitectura contemporánea, sitos en la provincia de Cádiz, que se relacionan en su Anexo, en la que se realizó un trámite de audiencia a los interesados y municipios afectados, pero no se sometió a información pública.

77 Aunque el Proyecto dice que la inclusión se realizará siempre de oficio, a continuación determina que cabe solicitud de inclusión por cualquier persona física o jurídica.

78 Ello vulnera lo dispuesto en el art. 43.1 de la LRJAPAC que establece como regla general el silencio positivo, salvo que se establezca el silencio negativo por Ley. Y ello porque la Ley $1 / 01$, de 12 de julio, que establece el plazo y el sentido del silencio en procedimientos tramitados por la Comunidad Autónoma, modificada por Decreto-Ley 1/09, de 24 de febrero, no ha incluido el procedimiento de inscripción de bienes en el Inventario de Bienes Reconocidos como uno de los supuestos de silencio negativo, lo que podía haberse hecho en dicho Decreto-Ley.

79 Debería añadirse "o caducado el procedimiento" para el caso en que el mismo se inicie de oficio.

80 Una vez inscritos dichos bienes y espacios en el Registro Administrativo de Instrumentos de Planeamiento, el órgano encargado de este Registro urbanístico comunicará a la actual Dirección General de Bienes Culturales e Instituciones Museísticas los bienes inmuebles o espacios objeto de inscripción y todos los datos necesarios para su completa descripción e identificación, incluyendo la indicación expresa 
En cuanto a la exclusión de bienes inmuebles y espacios del IBR, el art. 29 del Proyecto de Reglamento General de la LPHA establece que se seguirá el mismo procedimiento que para su inclusión ${ }^{81}$.

\section{RÉGIMEN JURÍDICO DE PROTECCIÓN APLICABLE A LOS BIENES QUE INTEGRAN EL PATRIMONIO HISTÓRICO ANDALUZ}

El Capítulo III, del Título I de la LPHA contiene un régimen general de protección aplicable principalmente a los bienes incluidos en el Catálogo General, así como, algunas determinaciones referidas a los bienes que integran el Inventario de Bienes Reconocidos. Analicemos este régimen general de protección.

\section{A. Régimen de protección aplicable a los bienes y actividades inscritos en el CGPHA}

La protección que se dispensa a estos bienes podemos clasificarla en atención a las obligaciones que dicha inscripción conlleva para los titulares de los bienes y las potestades administrativas que se reserva la Administración competente en materia de patrimonio histórico.

\section{a) Obligaciones de las personas titulares o poseedoras de estos bienes}

Las personas propietarias o simples poseedoras de bienes integrados en el CGPHA tienen las siguientes obligaciones (art. 14 LPHA), cuyas condiciones de cumplimiento se determinarán reglamentariamente:

- Conservar, mantener y custodiar el bien de manera que se garantice la salvaguardia de sus valores artísticos, históricos, arqueológico, documental, entre otros.

- Colaborar con la Administración pública, en concreto les corresponde: a) permitir la inspección por las personas y órganos competentes de la Administración de la Junta de Andalucía; b) admitir su estudio por las personas investigadoras acreditadas por dicha Administración; y c) facilitar la información que pidan las Administraciones públicas competentes sobre el estado de los bienes y su utilización.

\footnotetext{
del nivel de protección asignado por el Catálogo o instrumento urbanístico y los aspectos fundamentales de su régimen jurídico. Esta comunicación deberá efectuarse en el plazo de un mes a contar desde la inscripción del bien o espacio en el Registro (art. 27.2 del Proyecto).

81 Junto a los supuestos de exclusión expresa de bienes y espacios del Inventario, el Proyecto de Reglamento se refiere a un caso que podríamos calificar de exclusión implícita, que se produce cuando concluye el procedimiento de inscripción de un bien en el Catálogo General del Patrimonio Histórico si dicho bien figuraba en el citado Inventario (art. 20.3 del Proyecto).
} 
- Facilitar la visita pública gratuita cuando se trate de un BIC. Dicha visita deberá permitirse al menos 4 días al mes, en días y horas previamente señalados, constando esta información de manera accesible y pública a los ciudadanos en lugar adecuado del BIC. No obstante, este deber se relativiza por cuanto la Consejería competente en materia de patrimonio histórico puede dispensar total o parcialmente de aquella obligación cuando medie causa justificada.

De las citadas obligaciones han merecido una especial atención normativa la potestad de inspección de que goza la Administración de la Junta de Andalucía ${ }^{82}$ y la obligación de facilitar el estudio de los bienes integrados en el CGPHA por investigadores acreditados ${ }^{83}$. Ello contrasta con la falta de determinación de la obligación de facilitar la visita pública gratuita a los BIC, y sobre todo, de cuáles sean las "causas justificadas" que pueden llevar a la Consejería competente a dispensar total o parcialmente de dicha obligación.

\section{b) Potestades administrativas para la protección de los bienes inscritos en el CGPHA}

La LPHA recoge tres potestades administrativas que tienen por objeto la protección de los bienes inscritos en el CGPHA: a) el dictar órdenes de ejecución de obras o actividades para garantizar su conservación, mantenimiento y custodia; b) el ejercicio del derecho de tanteo y retracto en las transmisiones de los bienes inscritos; c) y, la más drástica, la expropiación total o parcial del bien. Estas potestades se encuentran principalmente en manos de la Consejería de Cultura y Deporte, pero no se excluye su ejercicio por los municipios.

\section{b.1. Órdenes de ejecución de obras y actividades de conservación, mantenimiento y custodia}

El art. 15 de la LPHA establece que la Consejería de Cultura y Deporte podrá ordenar a las personas titulares de bienes inscritos en el CGPHA la ejecución de obras o la realización de actividades que sean necesarias para su conservación, mantenimiento y custodia ${ }^{84}$. Estas órdenes de ejecución, a diferencia de las que pueden dictar los municipios en ejercicio de sus competencias de disciplina urbanística, no eximen a sus

82 La función de inspección se regula en los art. 103 a 105 de la LPHA y es desarrollada por el art. 21 del Decreto 19/95, de 7 de febrero.

83 Por lo que respecta a la obligación de facilitar el estudio de los bienes integrados en el CGPHA a los investigadores acreditados, el art. 22 del Decreto 19/95, de 7 de febrero regula las condiciones de cumplimiento.

84 El art. 23 del Decreto 19/95, de 7 de febrero, dispone que la Consejería, a la vista de los informes técnicos de los que se desprenda la necesidad de esas obras o actuaciones, notificará a los propietarios o titulares de derechos sobre los mismos las actuaciones a llevar a cabo, su coste y ejecución. 
destinatarios de la obligación de obtener de otras Administraciones públicas las licencias o autorizaciones que correspondan ${ }^{85}$.

En el caso en que el coste de las obras o actuaciones ordenadas por la Consejería excedieran del $50 \%$ del valor total del bien ${ }^{86}$, se pueden plantear dos supuestos:

- El primero, que la Consejería quiera adquirir el bien para ella o para un tercero, en cuyo caso los destinatarios de las órdenes de ejecución pueden liberarse de la carga ofreciendo a la Consejería, la transmisión de sus derechos sobre el bien ${ }^{87}$.

- El segundo, que la Consejería opte por no adquirir el bien ofrecido, en cuyo caso el propietario, titular del derecho o poseedor del bien vendrá obligado a adoptar únicamente aquellas previsiones que se declaren prioritarias por la Consejería y cuyo coste no supere el 50\% del valor del bien (art. 15.3 LPHA).

¿Pero qué medidas de ejecución forzosa cabe aplicar para el caso de que voluntariamente no se atienda a las órdenes de ejecución? Para el supuesto en que voluntariamente no se proceda a cumplir las órdenes de ejecución, ni -cuando se supere el 50\% del valor del bien- se opte por su transmisión o por ejecutar aquellas actuaciones que se declaren prioritarias por la Consejería, ésta podrá decidir la medida de ejecución forzosa que procede: la imposición de multas coercitivas ${ }^{88}$ o la ejecución subsidiaria ${ }^{89}$.

85 En este sentido, el art. 169.3 de la LOUA dispone que no están sujetas a previa licencia urbanística las obras que sean objeto de las órdenes de ejecución que se dicten por los municipios para la realización de obras de reparación, conservación y rehabilitación de edificios y construcciones deterioradas, en condiciones deficientes para su uso legítimo, o cuando se pretenda la restitución de su aspecto originario.

86 La LPHA de 2007 toma como referencia el límite al deber de conservación que tiene todo propietario, que la normativa urbanística fija en "la mitad del valor de una construcción de nueva planta, con similares características e igual superficie útil o, en su caso, de dimensiones equivalentes a la preexistente, realizada con las condiciones necesarias para que su ocupación sea autorizada" (art. 155.3 LOUA).

87 Esta posibilidad de liberarse de las órdenes de ejecución mediante transmisión del bien, regulada en la LPHA, difiere y prevalece -dado su rango normativo- sobre la regulación que de dicha liberación realiza el art. 26.1 del Decreto 19/95, de 7 de febrero, el cual la vincula a la "transmisión de cualquier título posesorio y del derecho de propiedad o usufructo por plazo superior a 25 años”. El nuevo art. 36 del Proyecto de Reglamento General de la LPHA contiene una redacción ajustada a lo dispuesto en el art. 15 de la LPHA.

88 La multa coercitiva es uno de los medios de ejercer la autotutela ejecutiva y carece, pues, de fundamento sancionador como reiteradamente ha manifestado el Tribunal Constitucional (STC22/84, de 17 de febrero, 144/87, de 23 de septiembre 0 239/88, de 14 de diciembre..., entre otras). Por ello no se entiende que el art. 37.3 del Proyecto de Reglamento General de la LPHA cuando se refiere a las multas coercitivas prevea que las impuestas por la Consejería competente en materia de patrimonio histórico en concepto de sanciones se destinarán a la conservación de los bienes integrantes del patrimonio histórico de que sea titular o gestione la Comunidad Autónoma de Andalucía. Si se está refiriendo a multas coercitivas, como parece indicar la ubicación de esta previsión normativa, sobra la referencia a "en concepto de sanciones", porque como dispone el art. 99.2 de la LRJAPAC “la multa coercitiva es independiente de las sanciones que puedan imponerse con tal carácter y compatible con ellas”. Si por el contrario se refiere a multas impuestas por infracciones cometidas a la normativa sobre patrimonio histórico andaluz, debe eliminarse como apartado $3^{\circ}$ del art. 37 dedicado a las multas coercitivas.

89 Art. 16 LPHA. Ello, sin perjuicio de la apertura del correspondiente expediente sancionador y del ejercicio, en su caso, de la potestad expropiatoria, como señala el art. 23.4 del Decreto 19/95, de 7 de febrero. 


\section{b.2. La potestad expropiatoria de bienes inscritos en el CGPHA o del entorno ${ }^{90}$}

El art. 18 de la LPHA prevé una potestad expropiatoria por causa de interés social muy amplia amparada en la existencia de bienes inscritos en el CGPHA. No solo se admite la expropiación de aquellos bienes sino que se permite la expropiación de bienes de su entorno. En el primer caso, dicha potestad puede ejercerla la Administración autonómica cuando se incumpla alguna de las obligaciones establecidas en la legislación de patrimonio histórico andaluz respecto de los bienes inscritos en el CGPHA, y puede ser una expropiación total o parcial del bien ${ }^{91}$. En el segundo supuesto, se consideran de interés social a efectos expropiatorios las obras y adquisiciones necesarias para la contemplación de bienes catalogados, para facilitar la conservación de los mismos o eliminar los usos incompatibles u otras circunstancias que atenten contra los valores y seguridad de aquellos bienes ${ }^{92}$.

El ejercicio de esta potestad expropiatoria lo ostenta la Administración de la Junta de Andalucía. No obstante, las Entidades locales podrán acordar también la expropiación de dichos bienes notificándolo previamente a la Administración autonómica, que goza de prioridad en su ejercicio ${ }^{93}$.

\section{b.3. La potestad de tanteo y retracto ${ }^{94}$}

El art. 17 de la LPHA regula la posibilidad de ejercer el derecho de tanteo y retracto que ostenta la Administración autonómica para sí, para los Entes locales o para otras entidades cuando se produzca la transmisión onerosa de bienes muebles o inmuebles inscritos en el CGPHA. Para ello el titular del bien o subastador viene obligado a notificar su enajenación a la Consejería de Cultura y Deporte y a los municipios donde radiquen los bienes.

La competencia para ejercer estas potestades la ostenta con carácter preferente la Consejería de Cultura y Deporte y, subsidiariamente, los municipios donde estén ubicados los bienes (art. 17.6 LPHA) 95

90 La expropiación de bienes de valor artístico, histórico y arqueológico se regula en el Capítulo III, del Título III de la Ley de Expropiación Forzosa de 1954 y en los arts. 92 a 96 de su Reglamento de desarroIlo; así como, en los arts.36.4 y 37.3 LPHE. Respecto de esta regulación, vid, Alegra Ávila, J.M. (1994):109110.

91 El art. 33 del Decreto 19/95, de 7 de febrero, exige una resolución motivada que declare aquel incumplimiento, tras la apertura de expediente en el que debe darse audiencia a los interesados.

92 Vid, art. 82 de la LEF y art. 34 del Decreto 19/95, de 7 de febrero.

93 Art. 18.3 LPHA. En el mismo sentido, el art. 37.3 de la LPHE y el art. 34, apdos. $2^{\circ}, 3^{\circ}$ y $4^{\circ}$ del Decreto 19/95, de 7 de febrero.

94 En relación al derecho de tanteo y retracto que puede ejercer el Estado sobre bienes de valor artístico, histórico y arqueológico, vid, arts.97 a 100 del Decreto 26 de abril de 1957, por el que se aprueba

64 el Reglamento de Expropiación Forzosa. 


\section{B. El indeterminado régimen de protección de los Bienes incluidos en el Inventario de Bienes Reconocidos del Patrimonio Histórico Andaluz}

La inclusión de bienes inmuebles en el IBR no conlleva un régimen de protección específico. La LPHA se limita a plasmar el deber de conservación, mantenimiento y custodia de dichos bienes por parte de las personas propietarias, titulares de derechos o simples poseedoras (art. 14.1 LPHA) y a reconocer el derecho de tanteo y retracto respecto de los bienes inmuebles situados en Conjuntos Históricos que estén incluidos en Catálogos y formen parte del Inventario de Bienes Reconocidos.

Ello deja en manos de los correspondientes Catálogos urbanísticos la determinación de su régimen de protección; lo que implica una gran diversidad y que bienes inventariados mediante Resolución de la Dirección General de Bienes Culturales y Instituciones Museísticas no se sometan al mismo hasta no verse reflejados en el correspondiente Catálogo urbanístico ${ }^{96}$.

Por tanto, será la planificación urbanística, a través de los Catálogos, la que determine el régimen de protección de los bienes incluidos en el Inventario de Bienes Reconocidos.

\section{LA PROTECCIÓN CONTRA LA CONTAMINACIÓN VISUAL O PERCEPTIVA ${ }^{97}$}

La LPHA resulta novedosa en cuanto su art. 19 se dedica a la protección del patrimonio histórico andaluz respecto a la contaminación visual o perceptiva ${ }^{98}$, respecto a la cual existen referencias parciales en la LPHE cuando se refiere a los bienes inmuebles $^{99}$ y en la legislación del suelo estatal ${ }^{100}$. La importancia de esta técnica de protec-

96 El art. 30 del Proyecto de Reglamento General de la LPHA se refiere al régimen de protección aplicable a los bienes incluidos en el IBR para establecer que será el previsto en el correspondiente Catálogo urbanístico o instrumento equivalente. Los incorporados por resolución de la Dirección General competente en materia de patrimonio histórico tendrán el máximo nivel de protección de su Catálogo hasta que se incluyan en el correspondiente Catálogo y se les asigne la protección que se considere adecuada a sus valores.

97 Entre otros, Ávila Rodríguez, C.Mª . (2007): .247-253; Molina Giménez, A. (2000): 327 y ss; Defensor del Pueblo Andaluz (1998).

98 Sobre la regulación contenida en la LPHA en materia de contaminación visual o perceptiva, entre otros, Martínez de Carvajal, A.I. (2008): 7.

99 Así, el art. 19 , apdos. $1^{\circ}$ y $2^{\circ}$ de la LPHE exige autorización administrativa para colocar en fachadas o cubiertas de monumentos declarados BIC cualquier rótulo, señal o símbolo, así como, para su colocación en jardines históricos declarados BIC. Además, se establece la prohibición de colocar publicidad comercial y de cualquier clase de cables, antenas y conducciones aparentes en los jardines históricos y en las fachadas y cubiertas de monumentos declarados BIC, así como, toda construcción que perturbe su contemplación (art. 19.3 LPHE). Dicha prohibición se extiende también a las zonas arqueológicas (art. 22.2 LPHE). Para dar cumplimiento a la prohibición prevista en el art. 19.3 se prevé un plazo de 5 años desde la entrada en vigor de la LPHE.

100 Al respecto, vid, el art. 10.2 del Real Decreto Legislativo 2/08, de 20 de junio, por el que se aprueba el Texto Refundido de la Ley del Suelo. Sobre esta materia véase: Hervás Más, J. (2009); Martín-RetortiIlo Baquer, L. (1973):423 y ss; Zoido Naranjo, F. y Venegas Moreno, C (coord) (2002). 
ción de bienes inmuebles incluidos en el CGPHA ha hecho que el Proyecto de Reglamento General de la LPHA dedique el Capítulo IV de su Título I a la misma. Veamos su concepto y los mecanismos de control y prevención que la normativa andaluza prevé frente a este tipo de agresión visual de los bienes históricos.

\section{A) Concepto}

El art. 19.1 de la LPHA define la contaminación visual o perceptiva como todo uso, acción o intervención en un bien, o en su entorno ${ }^{101}$, que degrade sus valores y toda interferencia que impida o distorsione su contemplación.

La contaminación visual o perceptiva se predica, pues, respecto de bienes inmuebles del patrimonio histórico, por tanto, se trata de bienes integrados en el CGPHA o en el Inventario de Bienes Reconocidos. Sin embargo, cuando analizamos las obligaciones que impone la legislación de patrimonio histórico andaluz respecto del planeamiento urbanístico, como veremos, se limita a la protección contra dicho tipo de contaminación que afecta a bienes inscritos en el CGPHA. Es más, se intensifica la protección en relación a determinados tipos de bienes inmuebles inscritos en dicho Catálogo.

\section{B) Instrumentos de ordenación y control de la contaminación visual o perceptiva}

La legislación andaluza de patrimonio histórico recoge mecanismos de ordenación y control de la contaminación visual y perceptiva de bienes inmuebles incluidos en el CGPHA, entre los que se incluyen instrumentos de planificación, previsiones normativas vinculantes y la técnica autorizatoria para la realización de actividades que puedan generar aquella contaminación.

Por lo que respecta a los instrumentos de ordenación urbanística, la LPHA prevé la obligación de los municipios donde radiquen bienes inscritos en el CGPHA de recoger en el planeamiento urbanístico o en las ordenanzas municipales de edificación y

Tradicionalmente la legislación del suelo estatal ha venido exigiendo que las edificaciones y construcciones se realicen de forma que no se limite "el campo visual para contemplar las bellezas naturales, se rompa la armonía del paisaje o se desfigure la perspectiva propia del mismo”, en definitiva, que se adapten al medio ambiente. Como vemos, todos ellos conceptos jurídicos indeterminados que exigen de su concreción en el caso concreto. No obstante el inconveniente que presenta esa genérica regulación de la contaminación visual que ha venido realizando la legislación estatal del suelo, ello no ha impedido su aplicación para la preservación y protección del patrimonio histórico. En este sentido, la Sentencia del Tribunal Supremo de 21 de noviembre de 2000 (Pte. Sanz Bayón, fj.7 y $8^{\circ}$ ), ha establecido que la construcción de edificaciones en la ladera de una colina en cuya cima se sitúa el Castillo de Aracena, declarado BIC, constituye claramente una agresión visual que rompe la armonía del paisaje, con lo que se considera que se vulnera el art. 138.b) del la Ley del Suelo de 1992, que regulaba la adaptación de las construcciones al entorno en el que se sitúan.

101 Dicho entorno lo forman los bienes inmuebles y espacios colindantes inmediatos o alejados, cuya alteración pueda afectar a los valores del bien, a su contemplación, apreciación o estudio (art. 28.1 LPHA). Sobre el entorno de los inmuebles de interés cultural, vid, Castillo Ruiz, J. (1997). 
urbanización medidas que eviten su contaminación visual o perceptiva. Dichas medidas deben controlar las instalaciones de red (energía y telecomunicaciones); la colocación del mobiliario urbano ${ }^{102}$ o los elementos para la recogida de residuos urbanos; la ubicación de rótulos, señales o publicidad exterior; y, las construcciones o instalaciones de carácter permanente o temporal que por su altura, volumetría o distancia puedan perturbar la percepción del bien ${ }^{103}$.

Esta obligación genérica prevista para todos los bienes inmuebles que integran el CGPHA se intensifica respecto de los bienes inmuebles declarados BIC que se clasifiquen como Conjuntos Históricos, Sitios Históricos, Lugares de Interés Etnológico, Lugares de Interés Industrial y Zonas patrimoniales, respecto de los cuales los planes urbanísticos que les afecten deben contener "las prescripciones para la conservación de las características generales del ambiente, con una normativa de control de la contaminación visual o perceptiva" (art. 31.1,f) de la LPHA).

Estas determinaciones sobre el planeamiento urbanístico impuestas por la legislación de patrimonio histórico de Andalucía vienen a concretar y pormenorizar las previsiones que al respecto $y$, de forma genérica, contiene la LOUA ${ }^{104}$. Especialmente útiles para evitar la contaminación visual resultan las Ordenanzas de Edificación por cuanto que tienen por objeto regular aspectos morfológicos, incluidos los estéticos y otras condiciones que sean exigibles para autorizar actos de construcción, edificación o usos susceptibles de realización en inmuebles. Las mismas deberán ajustarse a las disposiciones sectoriales reguladoras de "la protección del patrimonio urbanístico, arquitectónico, cultural, natural o paisajístico” (art. 24 LOUA).

Pero no queda aquí la protección que los municipios deben dispensar a estos bienes inmuebles, sino que están también obligados a elaborar un Plan de Descontaminación Visual o Perceptiva, que aprobará la Consejería de Cultura y Deporte ${ }^{105}$.

102 El Proyecto de Reglamento General de la LPHA en un afán por ampliar los elementos que deben ser objeto de control para evitar la contaminación visual o perceptiva de bienes inmuebles catalogados incluye como "mobiliario urbano" los toldos, veladores, quioscos y demás elementos análogos (art. 48.2,e), lo que consideramos un error por cuanto el mobiliario urbano lo forman bienes de dominio público de titularidad municipal, mientras que esos toldos, veladores, quioscos o elementos análogos que ocupan el dominio público municipal en virtud de autorización o concesión demanial suelen ser de titularidad privada a salvo de lo que se disponga en dichos títulos habilitantes. Este tipo de bienes podríamos considerarlos incluidos en el art. 19.2.a) de la LPHA cuando se refiere a instalaciones, de carácter permanente o temporal, que por su... distancia puedan perturbar la percepción del bien.

En la Sentencia del Tribunal Superior de Justicia de Andalucía de 28 de junio de 2000 (Pte. Estepa Moriana) se considera mobiliario urbano 7 naranjos y dos bancos, lo que, dado su pequeño porte, se estima que no afectan a la contemplación de una muralla medieval declara BIC, o sea, que no generan contaminación visual o perceptiva de dicho bien.

103 Art. 19.2 LPHA; art. 48 del Proyecto de Reglamento General de la LPHA.

104 Art. 9.A, c) y art. 10.A, g); arts. 14.1.b) y 16.1 de la LOUA. Respecto de los planes especiales de protección, entre otros: Barrero Rodríguez, C. (1993): 39 y ss.

105 Dicha aprobación debía realizarse en el plazo de tres años desde la entrada en vigor de la LPHA, plazo que finalizó en el año 2010 (Disposición Transitoria Tercera, párrafo $1^{\circ}$ de la LPHA), sin que el mismo haya visto la luz. 
Por otra parte, las actuaciones que se realicen en el entorno de bienes inmuebles inscritos como BIC en el CGPHA se sujetan a autorización administrativa con el objeto de evitar cualquier alteración que pueda afectar a los valores propios del bien o a su contemplación (arts.25 y 28 LPHA). Además, en fachadas o cubiertas de monumentos, jardines históricos y sus entornos, se necesita autorización para colocar cualquier clase de rótulo, señal o símbolos ${ }^{106}$.

Estas exigencias de autorización se complementan con varias prohibiciones: a) en jardines históricos y fachadas o cubiertas de monumentos se prohíbe la colocación de publicidad comercial y de cualquier clase de cable, antenas y conducciones aparentes (art. 33.2, párrafo $1^{\circ}$ de la LPHA) ${ }^{107}$; b) en los bienes inmuebles inscritos como BIC se prohíbe toda construcción que altere dicho carácter o perturbe su contemplación, sin perjuicio de que reglamentariamente puedan establecerse excepciones (art. 33.2, párrafo $2^{\circ}$ de la LPHA).

Como vemos, todo un conjunto de técnicas destinadas a garantizar una contemplación de los bienes históricos libre de interferencias que limiten su valor.

\section{REFLEXIÓN FINAL}

La LPHA contiene dos importantes instrumentos de protección para los bienes que integran el patrimonio cultural de Andalucía. Por una parte, el CGPHA, que ya preveía la anterior Ley de Patrimonio Histórico de 1991 y, por otra parte, el más novedoso Inventario de Bienes Reconocidos (IBR). En las líneas que anteceden nos hemos centrado en el análisis de los procedimientos para la inclusión de bienes en los mismos y en el régimen jurídico que ello conlleva.

Especial atención hemos prestado al papel que los municipios desempeñan en la protección y fomento del patrimonio histórico andaluz. Las importantes competencias que se les atribuyen contrastan con su escasa intervención en el procedimiento de inscripción de un bien en el instrumento de protección más relevante, el Catálogo General del Patrimonio Histórico Andaluz. Así, los municipios sólo pueden solicitar la incoación del procedimiento, que puede ser denegada. A la vez, deben ser notificados de dicha incoación y se les dará audiencia exclusivamente cuando se refiera a bienes inmuebles o actividades de interés etnológico. Dicha notificación resulta crucial si tenemos en cuenta que la Resolución de incoación de dicho procedimiento puede ordenar la redacción de instrucciones particulares aplicables a los BIC, las cuales, por su contenido, tienen una importante incidencia en la competencia urbanística municipal. Además, llama la atención aquella escasa intervención municipal respecto del procedimiento de inscripción de un bien en el CGPHA si lo ponemos en relación

106 Art. 33.3 y 39 de la LPHA.

107 El art. 85.2 del Proyecto de Reglamento General de la LPHA amplía esa prohibición a las zonas arqueológicas. Esta prohibición, que no se recoge en la LPHA, sí que está prevista en el art. 22.2 de la LPHE. 
con las obligaciones que la legislación de patrimonio histórico les atribuye en cuanto a evitar la contaminación visual o perceptiva de los bienes inmuebles. Mucho más relevante es el papel de los Ayuntamientos en la conformación del IBR, por cuanto éste se nutre de manera principal de aquellos bienes inmuebles incluidos en Catálogos urbanísticos.

Por otro lado, hemos querido destacar la necesidad de aprobación del desarroIlo reglamentario de la LPHA, dada la ausencia de desarrollo normativo de algunas materias (como el Inventario de Bienes Reconocidos), la existencia de previsiones jurisprudenciales no positivizadas o simplemente para evitar contradicciones con normas de rango superior. Al mismo tiempo, hemos resaltado las insuficiencias que presenta el Proyecto de Reglamento General de la LPHA sometido a información pública en 2011.

En definitiva, con el análisis de los instrumentos de protección del patrimonio histórico andaluz hemos querido poner de manifiesto la existencia de un conjunto de procedimientos orientados a la protección y tutela de los bienes culturales, carentes de simplificación y jalonados por un entrecruzamiento de competencias, especialmente intenso entre la Comunidad Autónoma y los municipios. Todo ello, consideramos que conlleva una complejidad que puede poner en riesgo el objetivo marcado, la protección, salvaguardia y fomento del patrimonio cultural.

\section{BIBLIOGRAFÍA}

Abad Liceras, J.M.: "La distribución de competencias entre el Estado y las Comunidades Autónomas en materia de patrimonio histórico-artístico: soluciones doctrinales" en Revista Española de Derecho Constitucional n 55 (1999); "El principio constitucional del derecho social a la cultura: análisis y manifestaciones", en Revista de Patrimonio Cultural y Derecho, $\mathrm{n}^{\circ}$ 6, (2002).

Alegre Ávila, J.M.: “Evolución y régimen jurídico del Patrimonio Histórico”, Ministerio de Cultura, Vol.I, II, Madrid, 1994.

Álvarez González, E.M.: La protección jurídica del patrimonio cultural subacuático en España. Ed. Tirant lo Blanch, Valencia, 2012.

Álvarez Royo-Villanova, S.: "El plazo para el pago en el derecho de tanteo de bienes culturales (Comentario a la sentencia del Tribunal Supremo de 21 de noviembre de 2006), en $R A P \mathrm{n}^{\circ} 176$ (2008).

Arana García, E.: "Competencias sobre cultura y patrimonio (Comentario al art. 68)" en la obra colectiva Comentarios al Estatuto de Autonomía de Andalucía (Dirs. Muñoz Machado y Rebollo Puig), Ed. Thonson-Civitas, Pamplona, 2008. "La cultura en el Estatuto de Autonomía de Andalucía”, en El Derecho de Andalucía del Patrimonio Histórico e Instituciones culturales (coord. Pérez Monguió, J.M. y Fernández Ramos, S.), IAAP, Sevilla, 2013

Ávila Rodríguez, C.M․: El Defensor del Pueblo y el Defensor del Pueblo Andaluz ante las políticas ambientales, Ed. Tirant Lo Blanch, Valencia, 2007. 
Barrero Rodríguez, C.: “La intervención de los bienes inmuebles del Patrimonio Histórico Español. La interpretación del art. 39.2 de la Ley del Patrimonio Histórico Español por la Sentencia del TS de 16 de octubre de 2000. La ilegalidad del Proyecto de Restauración y Rehabilitación del Teatro Romano de Sagundo" en $R A A P \mathrm{n}^{\circ} 40$ (2000); "La situación del Patrimonio Histórico en Andalucía. Un balance en el decimoquinto aniversario de su Estatuto de Autonomía", en RAAP n 27 (1996); "Las innovaciones de la Ley 14/07, de 26 de noviembre, del Patrimonio Histórico de Andalucía en la ordenación urbanística de los Conjuntos Históricos" en $R A A P \mathrm{n}^{\circ} 68$ (2007); “Los Conjuntos Históricos y el planeamiento de protección en la Comunidad Autónoma de Andalucía”, en $R A A P \mathrm{n}^{\circ}$ 16, (1993); La ordenación jurídica del patrimonio histórico, Madrid, Civitas, 1990; "Patrimonio Cultural y Derecho. La legislación Española y Andaluza” en Protección Jurídica del Patrimonio Cultural, Sevilla, IAAP, 2009; “El Derecho Andaluz del Patrimonio Histórico en el vigésimo aniversario del Estatuto de Autonomía” en $R A A P$, Número Extraordinario $2 / 2003$.

Bassols Coma, M.: “Los Conjuntos Históricos: su concepto en el ordenamiento jurídico español e internacional”, en Revista de Patrimonio Cultural y Derecho n 4 (2000).

Becerra García, J.M.: “El Patrimonio Histórico y Planeamiento Urbanístico en Andalucía” en la obra colectiva El nuevo marco legal del Patrimonio Histórico Andaluz. IAAP. Sevilla.2010.

Castillo Ruiz, J.: El entorno de los bienes inmuebles de interés cultural: concepto, legislación y metodología para su delimitación: evolución histórica y situación actual; ed. Servicio de Publicaciones de la Universidad de Granada, Granada, 1997.

Defensor del Pueblo Andaluz: La contaminación visual del Patrimonio Histórico Andaluz, Ed. Defensor del Pueblo Andaluz, febrero 1998, Sevilla.

Gamero Casado, E, Fernández Ramos, S.: Manual básico de Derecho Administrativo, Madrid, 2012.

García de Enterría, E.: “La Constitución como norma jurídica”, en La Constitución Española de 1978, dirigido por Predieri, A. y García de Enterría E., Madrid, 1980.

Gómez Barahona, A.: "Las competencias municipales en la protección del patrimonio cultural”, en Ciudades Patrimonio de la Humanidad de España, Urbanismo y Patrimonio Histórico, Ministerio de Educación, Cultura y Deporte, Madrid, 2001.

Hervás Más, J.: Ordenación del territorio, urbanismo y protección del paisaje: adaptado al Real Decreto Legislativo 2/08, de 20 de junio, por el que se aprueba el Texto Refundido de la Ley del Suelo; Ed. Bosch, Barcelona, 2009.

López Bravo, C.: "Regulación jurídica de los proyectos de conservación y restauración de bienes culturales", en Revista de Patrimonio Cultural y Derecho n 5 (2001).

Martín Retortillo, L.: "Problemas jurídicos de la tutela del paisaje", en $R A P \mathrm{n}^{\circ} 71$ (1973).

Martínez de Carvajal, A.I.: "La Ley de Patrimonio Histórico Andaluz (2007) y el planeamiento urbanístico", en Revista Electrónica de Patrimonio Histórico n 3 (2008).

Mellado Ruíz, L. y Roca Fernández, $M^{a}$ L.: "Régimen jurídico del patrimonio cultural inmaterial en Andalucía”, en la obra colectiva Patrimonio Cultural y Nuevas Tecnologías: entorno jurídico (Dir. Fernando Pablo), Ed. Ratio Legis, 2012.

70 tal”, en RAAP $\mathrm{n}^{\circ} 40$ (2000). 
Muñoz Machado, S.: "La resurrección de las ruinas: el caso del Teatro Romano de Sagunto" en Revista Urbanismo y Edificación nº 2 (2000).

Parada Vázquez, R.: Derecho Administrativo III. Bienes Públicos, Derecho Urbanístico, Marcial Pons, 2007.

Pazos Bernal, $M^{a}$ A.: "El patrimonio mueble en el nuevo marco legal del patrimonio histórico andaluz", en la obra colectiva Nuevo Marco Legal del Patrimonio Histórico Andaluz. IAAP, Sevilla, 2010.

Pérez de Armiñan, A.: Las competencias del Estado sobre el Patrimonio Histórico Español en la Constitución de 1978, Ed. Civitas, 1997.

Pérez Moreno, A.: "El postulado constitucional de la promoción y conservación del patrimonio histórico artístico", en Revista de Derecho Urbanístico n 119.

Prieto de Pedro, J.: Concepto y otros aspectos del patrimonio cultural en la Constitución, en la obra colectiva coordinada por Martín-Retortillo Baquer, S. Estudios sobre la Constitución Española: Homenaje al profesor Eduardo García de Enterría; Ed. Civitas, Madrid, 1991.

Sánchez Blanco, A.: "El Plan General de Bienes Culturales de Andalucía" en RAAP n 38 (2000).

Sánchez Goyanes, E.: "Técnicas urbanísticas de protección del Patrimonio Cultural en el Derecho Español" en Ciudades Patrimonio de la Humanidad de España, Urbanismo y Patrimonio Histórico, Ministerio de Educación, Cultura y Deporte, Madrid, 2001.

Vera Jurado, D.J. y Ildefonso Huertas, R: “La ordenación urbanística” en la obra colectiva Derecho Urbanístico de Andalucía (Comentarios a la Ley 7/02, de 17 de diciembre, de Ordenación Urbanística de Andalucía); Ed. Tirant Lo Blanch, Valencia, 2003.

Zoido Naranjo, F., y Venegas Moreno, C. (Coord): Paisaje y ordenación del territorio; Ed. Consejería de Obras Públicas y Transportes, Sevilla, 2002. 